\title{
Diffusion ability of endotoxin through dentinal tubules
}

\section{Avaliação da difusão de endotoxinas através dos túbulos dentinários}

\author{
Luciane Dias de Oliveira* \\ Cláudio Antonio Talge Carvalho** \\ Marcia Carneiro Valera*** \\ Cristiane Yumi Koga-Ito ${ }^{* * * *}$ \\ Antonio Olavo Cardoso Jorge $e^{* * * *}$
}

\begin{abstract}
The aim of this study was to evaluate the ability of endotoxin to diffuse through dentinal tubules towards the cement and to observe the period of time needed for it to reach the external root surface. Thirty singlerooted human teeth had their crowns and apices removed in order to standardize the root length to $15 \mathrm{~mm}$. Teeth were instrumented until \#30 K-file and made externally impermeable with epoxy adhesive, leaving $10 \mathrm{~mm}$ of the exposed root (middle third). The specimens were placed in plastic vials and irradiated (60Co gamma-rays). Then, they were divided into 2 groups ( $(=15)$ : G1) Escherichia coli endotoxin was inoculated into the root canal of the specimens and $1 \mathrm{ml}$ of pyrogen-free water was put in the tubes; G2) (control): pyrogen-free water was inoculated into the root canals and $1 \mathrm{ml}$ of pyrogen-free water was put in each tube. After $30 \mathrm{~min}, 2 \mathrm{~h}, 6 \mathrm{~h}, 12 \mathrm{~h}, 24 \mathrm{~h}, 48 \mathrm{~h}$, $72 \mathrm{~h}$ and 7 days, the water of the tubes was removed and replaced. The removed aliquot was tested for the presence of endotoxin. Considering that the endotoxin is a B-lymphocyte polyclonal activator, at each experimental period, B-lymphocyte culture was stimulated with a sample of water removed from each tube and antibody (IgM) production was detected by ELISA technique. The results of IgM production were higher in groups of $24 \mathrm{~h}, 48 \mathrm{~h}, 72 \mathrm{~h}$ and 7 days in relation to the other studied groups, with statistically significant differences (ANOVA and Tukey's test $\mathrm{p}<0.05)$. Endotoxin was able to diffuse through the dentinal tubules towards the cement, reaching the external root surface after the period of $24 \mathrm{~h}$.
\end{abstract}

DESCRIPTORS: Endotoxins; Tooth permeability; Dentin; Root canal.

RESUMO: O objetivo desta pesquisa foi avaliar in vitro a capacidade e o tempo necessário para a endotoxina se difundir pelos túbulos dentinários em direção ao cemento. Foram utilizados 30 dentes humanos unirradiculados, que tiveram suas coroas e seus ápices seccionados, padronizando-se o tamanho em $15 \mathrm{~mm}$. Os dentes foram instrumentados até a lima K30 e impermeabilizados externamente com adesivo epóxi, deixando-se $10 \mathrm{~mm}$ de raiz exposta (terço médio). Os espécimes foram acondicionados em tubos plásticos e submetidos à radiação gama cobalto 60. Após a radiação, foram divididos em 2 grupos $(n=15)$ : $G 1$ ) foi inoculada uma solução de endotoxina de Escherichia coli no canal radicular dos espécimes e $1 \mathrm{~mL}$ de água apirogênica foi colocado no interior dos tubos; G2 (controle): foi inoculada água apirogênica nos canais radiculares e $1 \mathrm{~mL}$ de água apirogência foi colocado em cada tubo. Após 30 min, 2 h, 6 h, 12 h, 24 h, 48 h, 72 h e 7 dias, a água do interior dos tubos foi removida e substituída por outra. A alíquota removida foi testada para se detectar presença de endotoxina através da produção de anticorpos (IgM) em cultura de linfócitos B, pois a endotoxina é um ativador policlonal dessas células. Os resultados foram submetidos à análise estatística ANOVA (5\%) e teste de Tukey, em que foi verificado que a água removida dos tubos após 24 h, 48 h, 72 h e 7 dias induziu maior produção de anticorpos em relação aos demais grupos, com diferença significante $(\mathrm{p}<0,05)$. Assim, a endotoxina foi capaz de se difundir pelos túbulos dentinários em direção ao cemento, atingindo a região externa da raiz após $24 \mathrm{~h}$.

DESCRITORES: Endotoxinas; Permeabilidade dentária; Dentina; Canal radicular.

\section{INTRODUCTION}

Bacterial infection is responsible for most pulpal and periapical inflammatory lesions ${ }^{10}$. Many factors affect the microbial growth and colonization in root canals, such as: nutrient concentration, low tension of oxygen in canals with necrotic pulp and bacterial interactions ${ }^{23}$. These factors allow the predominance of certain species, in particular of the genera Eubacterium, Peptococcus, Peptostrep-

\footnotetext{
*PhD Student; **PhD, Assistant Professor, Discipline of Endodontics; ***Adjunct Professor, Discipline of Endodontics; ****PhD, Assistant Professor, Discipline of Microbiology and Immunology; ${ }^{* * * *}$ Head Professor, Discipline of Microbiology and Immunology - School of Dentistry of São José dos Campos, São Paulo State University.
} 
Oliveira LD, Carvalho CAT, Valera MC, Koga-Ito CY, Jorge AOC. Diffusion ability of endotoxin through dentinal tubules. Braz Oral Res 2005;19(1):5-10.

tococcus, Prevotella, Porphyromonas and Fusobacterium $^{23}$. Analyses of the microflora in infected root canals with necrotic pulps and apical periodontitis have showed a predominance of Gram-negative anaerobic bacteria ${ }^{14}$.

The cell wall of Gram-negative bacteria contains endotoxins that are lipopolysaccharides (LPS) with potential cytotoxic action, released during bacterial multiplication or death ${ }^{2}$. Endotoxins are responsible for several important biological effects, such as: neutrophil chemotaxis; complement system activation; fever induction; structural, functional and metabolic alterations in many organs and cells; hemodynamic modifications ${ }^{9}$; B-lymphocyte polyclonal activation ${ }^{7,15}$; macrophage activation and release of several inflammatory mediators such as platelet activating factor (PAF), tumor necrosis factor (TNF), interleukins (IL-1, IL-6 and IL-8), superoxide $\left(\mathrm{O}_{2}^{-}\right)$, nitric oxide and prostaglan$\operatorname{din}^{2,19,20}$; and also osteoclasts' attraction. Some studies suggested that endotoxins are the main etiologic factor involved in the pathogenesis of the periapical inflammation, including bone resorption $^{17,26}$.

The effects of endotoxin on the periapical tissues of animals (monkeys, dogs and cats) are bone loss, and resorptive and inflammatory reactions in all experimental teeth ${ }^{13,17,22}$. Khabbaz et al. ${ }^{11}$ (2001) demonstrated the presence of endotoxin in the vital pulp of symptomatic and asymptomatic teeth. Endotoxin content in infected root canals was higher among symptomatic teeth, teeth with radiolucent areas and with exudation than in those without these alterations ${ }^{8,21}$. Dahlén, Bergenholtz ${ }^{6}$ (1980) observed that the endotoxic activity of the root canal samples was correlated with the presence and the number of Gram-negative bacteria in the root canal.

Elimination of microorganisms from the root canal system has been the major goal of endodontic treatment ${ }^{3}$. However, after bacterial death, endotoxin can remain and diffuse through dentin. Nissan et al. ${ }^{14}$ (1995) reported that endotoxin is capable of passing through $0.5 \mathrm{~mm}$ of dentin in apical direction. Endotoxin is also able to penetrate through obturation materials ${ }^{25}$ and can reach the periapical region faster (23 days) than bacteria (62 days) ${ }^{1}$. Horiba et al. ${ }^{8}$ (1991) studied the endotoxin content in serial dentin samples of infected root canals. These authors observed that this content was significantly higher in samples from the pulpal surface to $300 \mu \mathrm{m}$ in depth than in those taken farther toward the cementum side. However, little attention has been given to the capacity and velocity of endotoxin diffusion toward the cement.

The aim of this study was to evaluate in vitro the ability of endotoxin to diffuse through dentinal tubules towards the cement and to observe the period of time needed for this substance to reach the outer root surface.

\section{MATERIALS AND METHODS}

Thirty freshly extracted single-rooted human teeth were used in the study. These teeth were collected from patients of the School of Dentistry of São José dos Campos, São Paulo State University, Brazil, and the selection of teeth was made considering relative dimensions and similarity in morphology. Debris, calculus and soft tissue remnants on the root surfaces were cleaned using a Gracey curette (Duflex, Rio de Janeiro, RJ, Brazil) and the teeth were observed with a stereomicroscope (Zeiss, Oberkochen, Germany) to detect any cracks or damage in the root area. Compromised teeth were discarded. All teeth were stored in saline solution ( $\mathrm{NaCl}$ 0.85\%) (Merck, Darmstadt, Germany) until use. The selected specimens presented a diameter of approximately $4.5 \pm 0.5 \mathrm{~mm}$ in the middle third, measured with a vernier caliper (Marberg, China). The apical $3 \mathrm{~mm}$ of each root were transversely sectioned using a water-cooled diamond disc (Jon, SP, Brazil) and the crown was sectioned at a point in order to standardize the root length to approximately $15 \mathrm{~mm}$. Working length was determined by subtracting $1 \mathrm{~mm}$ from this measurement.

Canals were enlarged until \#30 K-file (Maillefer, Michigan, USA), so that the dentinal walls remained with $1.75 \pm 0.25 \mathrm{~mm}$ in thickness in the medium third. Buccolingual and mesiodistal radiographs were taken and evaluated with a scale for confirming this thickness. Canals were irrigated with $5 \mathrm{ml}$ of $1 \%$ sodium hypochlorite solution (Farmácia de Manipulação Aqua Marina, São José dos Campos, SP, Brazil) for each file used. The smear layer was removed with $17 \%$ EDTA (Farmácia de Manipulação Aqua Marina, São José dos Campos, SP, Brazil) for 3 min and specimens were washed with a final flush $(10 \mathrm{ml})$ of phosphate buffered saline (PBS) (Merck, Darmstadt, Germany) and dried with paper points (Dentsply, RJ, Brazil). The apical region was sealed with lightcured resin composite (3M Dental Products, St. Paul, USA) and the external surface of the apical and cervical thirds was covered with epoxy adhesive (Araldite, Brascola, São Paulo, SP, Brazil), except the $10 \mathrm{~mm}$ of the root middle third. 
Oliveira LD, Carvalho CAT, Valera MC, Koga-Ito CY, Jorge AOC. Diffusion ability of endotoxin through dentinal tubules. Braz Oral Res 2005;19(1):5-10.

All the roots were sterilized by autoclaving (Fanen, SP, Brazil) $\left(20 \mathrm{~min}\right.$ at $\left.121^{\circ} \mathrm{C}\right)$ and placed in plastic vials (Eppendorf, New York, USA). The specimens and all the material used in the experiment such as gauze, cotton, scissors and micropipette tips were irradiated with 60 Co gamma-rays for degradation of the pre-existing LPS ${ }^{5}$.

Under sterile conditions (laminar air flow chamber - Veco, SP, Brazil), $1 \mathrm{ml}$ of non-pyrogenic water (Charles River Endosafe, Charleston, SC, USA) was put in each plastic vial, so that the middle and apical thirds of the root were submerged. Then, the specimens were randomly assigned to 2 groups ( $\mathrm{n}=15)$ : $\mathrm{GE}$ (experimental group): $10 \mu \mathrm{l}$ (40 IU) of a standard solution containing Escherichia coli 055:B5 endotoxin (Sigma, St. Louis, USA) was inoculated in root canals; GC (control group): $10 \mu 1$ of non-pyrogenic water was inoculated in root canals. All the teeth were sealed with pyrogen-free cotton balls (Apolo, MG, Brazil) and the plastic vials were capped.

For evaluation of the presence of the endotoxin on the external root surfaces, water inside the tubes was removed and evaluated at different times after the inoculation of the endotoxin in the root canals. Eight experimental groups were obtained: GE1) after 30 min; GE2) after 2 hours; GE3) after 6 hours; GE4) after 12 hours; GE5) after 24 hours; GE6) after 48 hours; GE7) after 72 hours and GE8) after 7 days. In the control specimens, which received only non-pyrogenic water in the root canals, the removal of the water from the vials was accomplished at two times: GC1) after 24 hours and GC2) after 7 days. Immediately after water removal, another aliquot of non-pyrogenic water was transferred to all the vials $(n=30)$, which were maintained at $37 \pm 1^{\circ} \mathrm{C}$ under $100 \%$ humidity condition until the final period of 7 days.

Considering that the endotoxin is a B-lymphocyte polyclonal activator, at each experimental time B-lymphocyte culture was stimulated with a sample of water removed from each tube. Antibody production was detected by ELISA for verifying the presence of the endotoxin in the outer root surface.

\section{Antibody production in B lymphocyte culture}

Four male Swiss mice (Mus musculus) with approximately six months of age were sacrificed and the spleen of each animal was removed and macerated in a pyrogen-free Falcon tube (Becton Dickinson \& Co., NJ, USA) containing RPMI 1640 medium, pH 7.2 (Sigma, St. Louis, USA), to ob- tain B-lymphocytes. The tube was centrifuged at $534.8 \times \mathrm{g}$ for $10 \mathrm{~min}$ and the pellet was resuspended in $30 \mathrm{ml}$ of RPMI 1640 medium supplemented with $10 \%$ bovine fetal serum (Sigma, St. Louis, USA). In order to prevent contamination of the culture, sterile conditions were maintained by sterile laminar flow.

For cell viability verification, the trypan blue exclusion assay (0.4\%) (Sigma, St. Louis, USA) and a buffer (Sigma Chemical Co., St. Louis, MO, USA; Reagen, RJ, Brazil; Vetec, RJ, Brazil; Labsynth, SP, Brazil) to promote erythrocyte rupture were used. The viable cell count was $4.22 \times 10^{6}$ cells $/ \mathrm{mL}$. Approximately $1 \times 10^{6}$ viable cells $(250 \mu \mathrm{l})$ were transferred to each well of non-pyrogenic cell culture plates (24-well, Costar, NY, USA). These plates were incubated for $24 \mathrm{~h}$ at $37^{\circ} \mathrm{C}$ in a humidified atmosphere of $5 \%$ carbon dioxide $\left(\mathrm{CO}_{2}\right.$ - Nuaire, Minnesota, USA). B-lymphocytes of each well of cell culture plates were stimulated with an aliquot of $30 \mu 1$ of the water removed from each plastic tube, at the different periods of time. Fifteen wells containing only pure cell culture were considered the cell culture control group (GC3). The plates were incubated at $37^{\circ} \mathrm{C}$ in a humidified atmosphere of $5 \% \mathrm{CO}_{2}$ and $95 \%$ air for four days. The enzymelinked immunosorbent assay (ELISA) was used to determine the total IgM levels in the culture supernatant.

ELISA was performed in six microplates (96well, Hemobag, São Paulo, SP, Brazil). All the plates were coated with mouse anti-immunoglobulin M (Sigma, St. Louis, USA) at a concentration of $0.5 \mathrm{mg} / \mathrm{ml}$. The plates were incubated for $2 \mathrm{~h}$ at $37^{\circ} \mathrm{C}$ and maintained in the refrigerator until use.

At the day of the experiment, plates were blocked with $0.5 \%$ gelatin (Sigma Chemical Co., St. Louis, MO, USA) (G) in phosphate buffered saline (PBS) (Merck, Darmstadt, Germany) and $0.2 \%$ bovine serum albumin (BSA) (Sigma, St. Louis, USA) $\left(45 \mathrm{~min}\right.$ at $\left.37^{\circ} \mathrm{C}\right)$. Culture supernatants $(100 \mu 1)$ were added to each well and incubated at $37^{\circ} \mathrm{C}$ for $2 \mathrm{~h}$, followed by washing with $0.1 \%$ Tween-20 in PBS (Merck, Darmstadt, Germany) (PBS-T). All the tests were performed in duplicate. Anti-mouse IgM peroxidase conjugate (Sigma, St. Louis, USA), diluted 1,000 times with PBS-GT (0.5\% gelatin and $0.1 \%$ Tween-20 in PBS) (Merck, Darmstadt, Germany), was added to the plates, which were then incubated for $1 \mathrm{~h}$ at $37^{\circ} \mathrm{C}$. After washing with PBS-T, peroxidase enzyme activity was detected by addition of the substrate, $50 \mu 1$ of o-phenylenediamine (Sigma Chemical Co., St. 
Oliveira LD, Carvalho CAT, Valera MC, Koga-Ito CY, Jorge AOC. Diffusion ability of endotoxin through dentinal tubules. Braz Oral Res 2005;19(1):5-10.

Louis, MO, USA) $(1 \mathrm{mg} / \mathrm{ml})$ in solution of $0.1 \mathrm{M}$ citrate (Merck, Darmstadt, Germany) and 0.03\% $\mathrm{H}_{2} \mathrm{O}_{2}$ (Bioquímica, São José do Rio Preto, Brazil) for $10 \mathrm{~min}$. Finally, the reaction was stopped with $2.5 \mathrm{~N} \mathrm{H}_{2} \mathrm{SO}_{4}$ (Merck, Darmstadt, Germany). The optical density values (OD) of the wells were read at an absorbance of $490 \mathrm{~nm}$ on a Bio-Rad Microplate reader Model 3550 (Bio-Rad Laboratories, Hercules, California). For each specimen, OD mean values were obtained and the results were analyzed statistically by ANOVA and Tukey's test. The level of significance was established at $5 \%(p=0.05)$.

\section{RESULTS}

Optical density (OD) mean values and standard deviation obtained for each experimental group, according to the evaluated period, are presented in Table 1.

Stimulation of antibody (IgM) production in Blymphocyte culture with aliquots of water removed from some experimental groups - GE1 (30 min), GE2 (2 h), GE3 (6 h), GE4 (12 h) - was similar to that of the control groups - GC1 $(24 \mathrm{~h}), \mathrm{GC} 2$ (7 days) and GC3 (pure cell culture) - ( $p>0.05)$, demonstrating the absence of endotoxin in the external root surface in these groups. The aliquots removed from the GE5 group ( $24 \mathrm{~h}$ ) induced higher IgM production than those of all the other experimental and control groups ( $p<0.05)$, showing the presence of endotoxin in the external root surface after a period of 24 hours. The results obtained for groups GE6 (48 h), GE7 (72 h) and GE8 (7

TABLE 1 - Optical density (OD) mean values and standard deviation obtained for each group.

\begin{tabular}{l|c|c}
\hline \multicolumn{1}{c|}{ Groups } & $\begin{array}{c}\text { Mean values } \\
\text { (OD) }\end{array}$ & $\begin{array}{c}\text { Standard } \\
\text { deviation }\end{array}$ \\
\hline GE1 (30 min) & 222.8 & 25.9 \\
\hline GE2 (2 h) & 221.2 & 27.7 \\
\hline GE3 (6 h) & 225.9 & 18.6 \\
\hline GE4 (12 h) & 232.5 & 19.7 \\
\hline GE5 (24 h) & 509.6 & 23.2 \\
\hline GE6 (48 h) & 402.0 & 21.1 \\
\hline GE7 (72 h) & 409.4 & 26.8 \\
\hline GE8 (7 days) & 423.0 & 21.9 \\
\hline GC1 (24 h) & 227.4 & 20.6 \\
\hline GC2 (7 days) & 229.5 & 25.6 \\
\hline GC3 (pure cell culture) & 213.0 & 25.9 \\
\hline \hline
\end{tabular}

GE: experimental group; GC: control group. days) were similar ( $p>0.05)$; and these results were higher than those obtained for control groups $(\mathrm{p}<0.05)$, also demonstrating the presence of endotoxin in these experimental groups. GC1 (24 h) and GC2 (7 days) control groups presented similar results in relation to GC3 control group (pure cell culture) $(p>0.05)$, indicating the absence of the endotoxin.

\section{DISCUSSION}

In this study, the endotoxin used was from Escherichia coli, since it is the standard endotoxin used in most of the studies ${ }^{2,13,22}$. Chemically, endotoxins are lipopolysaccharides that consist of three different parts: a non-polar lipid component, called lipid A, the core oligosaccharide and a heteropolysaccharide representing the surface antigen (O-antigen). The $\mathrm{O}$-antigen is built up of a chain of repeated oligosaccharide units, which are strain specific and determinative for the serological identity of the respective bacterium ${ }^{16,18}$. The core oligosaccharide has a conserved structure with an inner KDO (2-keto-3-deoxyoctonic acid)-heptose region and an outer hexose region ${ }^{16}$. However, lipid $\mathrm{A}$ is the main component responsible for the endotoxic activity of LPS and its primary structure is well conserved among different species of Gram-negative bacteria ${ }^{12}$. Lipid A carries a total negative load due to the presence of three phosphoryl radicals and two to three carboxyl radicals associated with the inner region of the core, and another two phosphoryl radicals associated with the disaccharide part of the lipid ${ }^{16,18}$. Considering this, even if $E$. coli is not commonly found in root canals with necrotic pulps, its endotoxin presents the basic structure of the lipid component, which represents the responsible active center for the properties of LPS.

The test of B-cell stimulation was used in this study to observe the presence of the endotoxin in the samples based on the mitogenic effect of LPS on B-lymphocytes ${ }^{7}$. Oliveira et al. ${ }^{15}$ (2005), in a previous study, reported the use of this methodology to evaluate the effect of intracanal medication on LPS. In the presence of endotoxin, B-lymphocytes proliferate and produce antibodies that are detected by ELISA. Endotoxin is a T-independent antigen and has the capacity of activating various B cell clones. Considering this, we accomplished the cell culture using mice spleen ${ }^{15}$, which represents an important lymphoid secondary organ. To observe antibody production in the presence of the endotoxin, an interval of 4 days after the placement 
Oliveira LD, Carvalho CAT, Valera MC, Koga-Ito CY, Jorge AOC. Diffusion ability of endotoxin through dentinal tubules. Braz Oral Res 2005;19(1):5-10.

of the samples in the cell culture was maintained, because it is considered a period of time which is enough for the proliferation and transformation of the cells into plasmocytes. The polyclonal activation of the B-cells in vitro and in mice increases the synthesis of IgM more than that of $\operatorname{IgG}^{4}$. In this study, the increase in the production of IgM antibodies was detected using an anti-mouse IgM peroxidase conjugate by enzyme immunosorbent assay.

Higher antibody production could be observed in GE5 (24 h), GE6 (48 h), GE7 (72 h) and GE8 (7 days) groups. These results indicate that the endotoxin presented the capacity to diffuse through the dentinal tubules, in agreement with the reports of Nissan et al. ${ }^{14}$ (1995). These authors studied the ability of bacterial endotoxin to diffuse through human dentin in apical direction and concluded that endotoxin was capable of passing through $0.5 \mathrm{~mm}$ of dentin in a period that ranged from 15 min to $41 / 2 \mathrm{~h}$, so that the dentin may act as a semipermeable barrier, thus allowing the passage of bacterial products to the pulp. In the present study, we evaluated the ability of the endotoxin to diffuse through dentinal tubules toward the cement. Considering that the specimens presented dentinal walls of approximately $1.75 \mathrm{~mm}$ in thickness, the requested time for the endotoxin to reach the outer root surface was of $24 \mathrm{~h}$. Horiba et al. ${ }^{9}$ (1990) evaluated the endotoxin content in a series of samples of dentin from the pulpal surface of infected root canals to the cementum, independently of the time, and observed that the endotoxin content was significantly higher in samples from the pulpal surface of dentin to $300 \mu \mathrm{m}$ in depth than in those samples from 301 to $800 \mu \mathrm{m}$ toward the cementum side.

The present study demonstrated that the endotoxin has the capacity to diffuse deeply through dentinal tubules towards the cement. These data could be of great importance in endodontic practice since they suggest that dentinal tubules can be LPS reservoirs. Endotoxins, if not detoxified during the treatment, could diffuse through dentinal tubules, return to the canal or penetrate obturation materials and reach the periapical tissues, inducing or maintaining a periapical lesion. In this way, due to the depth of diffusion of endotoxins inside the dentinal tubules, we believe that the concomitant use of irrigation agents and intracanal medications with capacity of detoxifying LPS is essential ${ }^{15,24}$ in order to warrant the success of endodontic treatments.

\section{CONCLUSIONS}

Considering the results obtained in this study, it can be concluded that endotoxin diffused through dentinal tubules toward the cement, reaching the outer root surface after the period of $24 \mathrm{~h}$.

\section{REFERENCES}

1. Alves J, Walton R, Drake D. Coronal leakage: endotoxin penetration from mixed bacterial communities through obturated, post-prepared root canals. J Endod 1998;24(9):587-91.

2. Barthel CR, Levin LG, Reisner HM, Trope M. TNF- $\alpha$ release in monocytes after exposure to calcium hydroxide treated Escherichia coli LPS. Int Endod J 1997;30(3):155-9.

3. Byström A, Sundqvist G. Bacteriologic evaluation of the effect of 0.5 percent sodium hypochlorite in endodontic therapy. Oral Surg Oral Med Oral Pathol 1983;55:307-12.

4. Clagett J, Engel D, Chi E. In vitro expression of immunoglobulin $\mathrm{M}$ and $\mathrm{G}$ subclasses by murine B Lymphocytes in response to a polyclonal activator from Actinomyces. Infect Immun 1980;29(1):234-43.

5. Csako G, Elin RJ, Hochstein HD, Tsai CM. Physical and biological properties of U.S. standard endotoxin EC after exposure to ionizing radiation. Infect Immun 1983;41(1):190-6.

6. Dahlén G, Bergenholtz G. Endotoxin activity in teeth with necrotic pulps. J Dent Res 1980;59(6):1033-40.

7. Harper N, Connor K, Steinberg M, Safe S. An enzyme-linked immunosorbent assay (ELISA) specific for antibodies to TNP-LPS detects alterations in serum immunoglobulins and isotype switching in C57BL/ 6 and DBA/2 mice exposed to 2,3,7,8-tetrachlorodibenzo-p-dioxin and related compounds. Toxicology 1994;92(1-3):155-67.
8. Horiba N, Maekawa Y, Abe Y, Ito M, Matsumoto T, Nakamura $\mathrm{H}$. Correlations between endotoxin and clinical symptoms or radiolucent areas in infected root canals. Oral Surg Oral Med Oral Pathol 1991;71(4):492-5.

9. Horiba N, Maekawa Y, Matsumoto T, Nakamura H. A study of the distribution of endotoxin in the dentinal wall of infected root canals. J Endod 1990;16(7):331-4.

10. Kakehashi S, Stanley HR, Fitzgerald RJ. The effects of surgical exposures of dental pulps in germ-free and conventional laboratory rats. Oral Surg Oral Med Oral Pathol 1965;20:340-9.

11. Khabbaz MG, Anastasiadis PL, Sykaras SN. Determination of endotoxins in the vital pulp of human carious teeth: association with pulpal pain. Oral Surg Oral Med Oral Pathol Oral Radiol Endod 2001;91(5):587-93.

12. Kirikae T, Nakano M, Morrison DC. Antibiotic-induced endotoxin release from bacteria and its clinical significance. Microbiol Immunol 1997;41(4):285-94.

13. Nelson-Filho P, Leonardo MR, Silva LAB, Assed S. Radiographic evaluation of the effect of endotoxin (LPS) plus calcium hydroxide on apical and periapical tissues of dogs. J Endod 2002;28:694-6. 
Oliveira LD, Carvalho CAT, Valera MC, Koga-Ito CY, Jorge AOC. Diffusion ability of endotoxin through dentinal tubules. Braz Oral Res 2005;19(1):5-10.

14. Nissan R, Segal H, Pashley D, Stevens R, Trowbridge H. Ability of bacterial endotoxin to diffuse through human dentin. J Endod 1995;21(2):62-4.

15. Oliveira LD, Leão MVP, Carvalho CAT, Valera MC, Jorge AOC, Unterkircher CS, et al. In vitro effects of calcium hydroxide and polymyxin B on endotoxins in root canals. J Dent 2005;33:107-14.

16. Petsch D, Anspach FB. Endotoxin removal from protein solutions. J Biotechnol 2000;76(2-3):97-119.

17. Pitts DL, Williams BL, Morton TH Jr. Investigation of the role of endotoxin in periapical inflammation. J Endod $1982 ; 8(1): 10-8$.

18. Rietschel ET, Kirikae T, Schade FU, Ulmer AJ, Holst $\mathrm{O}$, Brade $\mathrm{H}$, et al. The chemical structure of bacterial endotoxin in relation to bioactivity. Immunobiol 1993;187 (3-5):169-90.

19. Safavi KE, Nichols FC. Alteration of biological properties of bacterial lipopolysaccharide by calcium hydroxide treatment. J Endod 1994;20(3):127-9.
20. Safavi KE, Nichols FC. Effect of calcium hydroxide on bacterial lipopolysaccharide. J Endod 1993;19(2):76-8.

21. Schein B, Schilder H. Endotoxin content in endodontically involved teeth. J Endod 1975;1(1):19-21.

22. Silva L, Nelson-Filho P, Leonardo MR, Rossi MA, Pansani CA. Effect of calcium hydroxide on bacterial endotoxin in vivo. J Endod 2002;28:94-8.

23. Sundqvist G. Associations between microbial species in dental root canal infections. Oral Microbiol Immunol 1992; 7:257-62.

24. Tanomaru Filho M, Leonardo MR, Silva LA, Aníbal FF, Faccioli LH. Inflammatory response to different endodontic irrigating solutions. Int Endod J 2002;35:735-9.

25. Trope $\mathrm{M}$, Chow $\mathrm{E}$, Nissan $\mathrm{R}$. In vitro endotoxin penetration of coronally unsealed endodontically treated teeth. Endod Dent Traumatol 1995;11(2):90-4.

26. Wang C, Stashenko P. The role of interleukin-1 $\alpha$ in the pathogenesis of periapical bone destruction in a rat model system. Oral Microbiol Immunol 1993;8(1):50-6.

Received for publication on Nov 12, 2004

Sent for alterations on Feb 11, 2005

Accepted for publication on Mar 04, 2005 